\title{
Morphometrics characterization in White Fulani, Muturu and Pasundan cows
}

\author{
Ridwan Olawale Ahmed ${ }^{1}$, Widya Pintaka Bayu Putra ${ }^{* 2}$, Johar Arifin ${ }^{3}$, Semiu Folaniyi Bello ${ }^{4}$ \\ ${ }^{1}$ Department of Animal and Avian Sciences, University of Maryland, College Park, USA \\ ${ }^{2}$ Research Center for Biotechnology, Research Organization of Life Science, National Research and Innovation \\ Agency (BRIN), Cibinong, 16911, Indonesia \\ ${ }^{3}$ Faculty of Animal Science, Padjadjaran University, Jatinangor 45363, Indonesia \\ ${ }^{4}$ Department of Animal Genetics, Breeding and Reproduction, College of Animal Science, South China \\ Agricultural University, Guangzhou 510642, Guangdong, China \\ *Correspondence: widya.putra.lipi@gmail.com
}

Received: June $1^{\text {th }}, 2021$; Accepted: November $9^{\text {th }}, 2021$; Published online: November 17 ${ }^{\text {th }}, 2021$

Abstrak

Tujuan: Tujuan dari penelitian ini adalah untuk melakukan karakterisasi pada tiga (3) bangsa sapi berbeda berdasarkan morfometri.

Metode: Lima (5) morfometri yaitu panjang badan (PB), lingkar dada (LD), tinggi gumba (TG), lebar pinggul (LP) dan dalam dada (DD) diukur pada masing-masing sapi. Sebanyak 119 ekor sapi betina terdiri dari White Fulani (40 ekor), Muturu (40 ekor) dan Pasundan (39 ekor) digunakan dalam penelitian ini. Rata-rata umur sapi pada penelitian ini adalah 20,93 $\pm 1,62$ bulan (White Fulani), 21,63 $\pm 1,75$ bulan (Muturu) dan 20,46 $\pm 2,99$ bulan (Pasundan). Metode canonical discriminant analysis $(C D A)$ dan herarchical cluster analysis (HCA) digunakan pada penelitian untuk melakukan karakterisasi pada sapi berdasarkan morfometri menggunakan program SPSS 16.0.

Hasil: Sebagian besar ukuran morfometri sapi White Fulani dan Pasundan terlihat sama sedangkan pada sapi Muturu secara signifikan terlihat paling kecil dibandingkan dua bangsa lainnya. Empat ukuran morfometri yaitu LD, LP, PL dan TG merupakan variabel pembeda pada sapi bedasarkan metode CDA. Metode CDA dengan ukuran tubuh mampu mengelompokkan sapi sebesar $85 \%$ (White Fulani), 100\% (Muturu) dan 74\% (Pasundan) pada kelompok bangsanya.

Kesimpulan: Kedekatan hubungan antara sapi White Fulani dan Pasundan dapat disebabkan karena keduanya merupakan bangsa sapi Bos indicus dan tidak seperti Muturu yang merupakan bangsa sapi Bos brachyceros.

Kata Kunci: CDA; HCA; sapi; ukuran morfometri

\section{Abstract}

Objective: This study was aimed to characterize three different cattle breeds based on the morphometrics.

Methods: Five (5) morphometrics which include body length (BL), chest girth (CG), withers height $(\mathrm{WH})$, rump length (RL) and chest depth (CD) were measured in each animal. A total of 119 cows belonging to White Fulani (40 heads), Muturu (40 heads) and Pasundan ( 39 heads) were used in this study. The age of animal study was $20.93 \pm 1.62$ months (White Fulani), $21.63 \pm 1.75$ months (Muturu) and 20.46 \pm 2.99 months (Pasundan). Hence, two statistical methods of canonical 
discriminant analysis (CDA) and hierarchical cluster analysis (HCA) methods were computed in this study to characterize of animals based on their morphometrics using SPSS 16.0 package.

Results: Mostly the morphometrics of White Fulani and Pasundan cows are similar while those of Muturu are significantly lower than the two other breeds. Four morphometric measurements of CG, RL, BL and WH were identified as a discriminator variables in animal study based on the CDA method. The CDA of morphometrics able to classify 85\% (White Fulani), 100\% (Muturu) and $74.4 \%$ (Pasundan) of the animal into their original breed group.

Conclusions: The closeness between observations from White Fulani and Pasundan might be due to them being both Zebu (Bos indicus) unlike the Muturu with a type breed of Bos bracycheros.

Keywords: cattle; CDA; HCA; morphometrical measurements

\section{INTRODUCTION}

Asia and Africa are known as the two central habitats of Bos indicus cattle [1]. From 4,000 to 1,300 years before present, Bos indicus was expanded from Indus valley (Asia) to Africa [2]. Hence, most of the native cattle in Asia and African countries have the genetic introgression from Bos indicus. However, the genetic introgression of Bos javanicus (Banteng) was found in many native cattle breeds in Southeast Asia, mainly Indonesia [3]. One of the native cattle breeds from Indonesia is Pasundan. This breed of cattle was adapted well at Java island and kept for meat production. According to Cyt-B and COI regions of mtDNA, Pasundan cattle has genetic introgression from Bos javanicus and Bos indicus, respectively [3,4]. Therefore, Muturu (West African Dwarf Shorthorn) and White Fulani (Bunaji) are dual purpose cattle type that originated from Nigeria. According to the D-loop region of mtDNA, White Fulani is a Zebu (Bos indicus) type of cattle that closed to the European cattle breed (Bos taurus) [5]. Meanwhile, Muturu cattle is a native cattle from West African sub-region with the least characterized Shorthorn (Brachyceros) humpless Bos taurus [6]. Mostly White Fulani, Muturu and Pasundan cattle were kept by the farmers with extensive system.

Genetic relationships between livestock breeds can be observed by discriminating the breeds either based on genomic information and morphological measurements. Discriminating in the livestock can be assessed through mitochondrial DNA (mtDNA) and morphometrical measurements. Although using genomic information is more accurate for breed differentiation, discrimination of breeds with morphometric measurement can be a first step to observe similarity among livestock breeds [7]. Previous studies have been used the morphometrical measurements to differentiate between breeds of cattle in India [8], Nigeria [9], Ethiopia [10] and Indonesia [11].

The purpose of this study was carried out to observe the morphometrics similarity among White Fulani, Muturu and Pasundan cows since these breeds have different genetics introgression. The results in this study can be used as the early information to observe the genetic relationship between Indonesian and Nigerian cattle.

\section{MATERIALS AND METHODS}

\section{Data collection and animal source}

The records data of morphometrical measurements from White Fulani (40 heads), Muturu (40 heads) and Pasundan (39 heads) cows were used in this study. The phenotypic characteristics of these breeds were ilustrated in Figure 1. The records data of White Fulani $(20.93 \pm 1.62$ months of age) and Muturu $(21.63 \pm 1.75$ months of age) cows were collected from the farmers at Ipokia Local Government Area, Ogun state and Oyo West Local Government Area, Oyo state of Nigeria. Meanwhile the records data of Pasundan cows (20.46 \pm 2.99 months of age) were collected from Breeding Station (BPPIB Cijeunjing) at Ciamis Regency, West Java Province of Indonesia.

\section{Animals management}

White Fulani and Muturu cows were managed semi-intensively by the farmers of Nigeria. They were fed with feed block (composition not provided) in the morning 

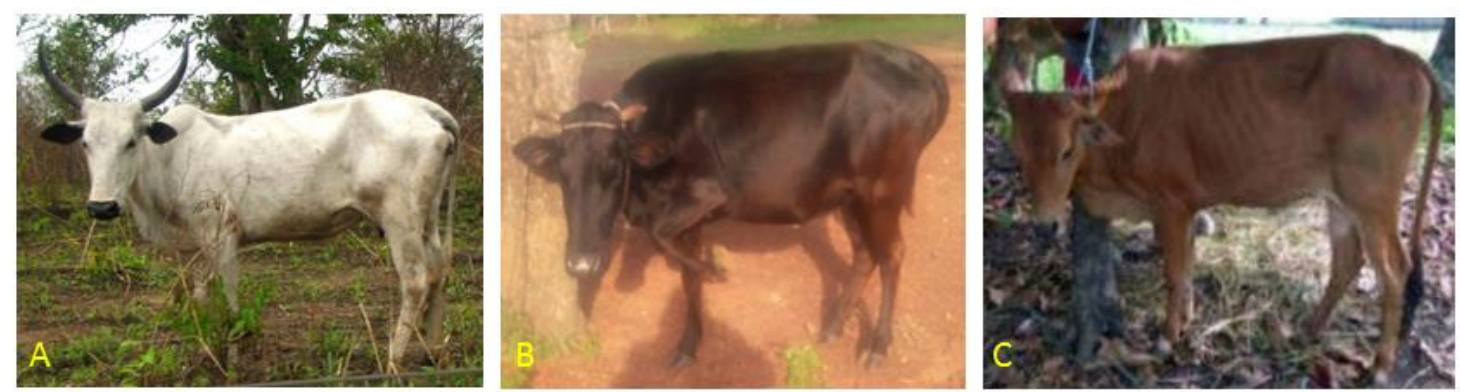

Figure 1. Phenotypic characteristics of White Fulani (A), Muturu (B) and Pasundan (C) cows

after which they are allowed to go for grazing till evening during the raining season while chopped forages are provided for them in dry season. They were provided with shed. No specific breeding program was adopted (allowed to mate randomly) by the cattle owners. In order to prevent inbred population during the sampling, matured individuals (2-3 cattle per farmer) were sampled from different farmers apart. Pasundan cows were managed intesively in the colony stall. Amount $2 \mathrm{~kg} / \mathrm{head}$ of commercial concentrate and $25 \mathrm{~kg} / \mathrm{head}$ of Elephant grass (Pennisetum purpureum) were given in the animal. The artificial insemination (AI) method was managed in each cow with Pasundan frozen sperm. Hence, the inbred population during sampling can be prevented according to the pedegree records in each animal.

\section{Morphometrical measurements}

Five morphometrics of $\mathrm{BL}, \mathrm{CG}, \mathrm{WH}$, RL and $\mathrm{CD}$ were measured according to the methods reported by a privous studies $[12,13]$. Briefly, BL was measured from Tuber humerus to Tuber ischium. CG was measured with a tape measure as circumference of the chest just behind the foreleg (fourth Os $\cos (a)$. WH was measured from the behind of Os scapulla at dorsal point to the ground. RL was measured from hips (Tuber coxae) to pins (Tuber ischii). CD was measured as the distance between the highest point of the processus spinalis of the vertebra thoracica to the lowest point of the chest. All measurements were taken by measuring wooden stick and taken from the right side of the animals.

\section{Statistical analysis}

Means and standard deviation of the morphometrical measurements were computed with general linear model (GLM) using a mathematical model as follows:

$$
Y_{\mathrm{ij}}=\mu+\sigma_{i}+\varepsilon_{\mathrm{ij}}
$$

Where, $Y_{i j}$ is the common means; $\sigma_{i}$ is the $\mathrm{i}^{\text {th }}$ morphometrical measurements; $\varepsilon_{\mathrm{ij}}$ is the common error. Thus, a canonical discriminant analysis (CDA) was performed to calculate Mahalanobis distance $\left(\mathrm{D}^{2}\right)$, tolerance $(\mathrm{T})$, Wilk's lambda $(\lambda)$ values and the discriminator variables. Thereafter, the CDA was applied with the backward stepping automatic elimination method for the variables, with $F$ value entry $=3.84$ and $\mathrm{F}$ value removal $=2.71$. The $\mathrm{T}$ value (0 to 1 ) was computed to detect the level of correlation among variables in the discriminant function. If a variable is highly correlated with one or more of the others, the $T$ value is very small, and the resulting estimates of the discriminant function coefficients may be unstable. The hierarchical cluster analysis (HCA) was used for clustering in each breed with the squared Mahalonobis ( $\left.\mathrm{D}^{2}\right)$ distance. The HCA in this study was performed using the morphometric measurements with the nearest-neighbor method and computed using SPSS 16.0 computer program.

\section{RESULTS}

The morphometrics of Muturu were lower than those observed in White Fulani and Pasundan cows (Table 1). Meanwhile, the highest morphometrics was shown in White Fulani cows than the other breeds. In addition, two canonical functions were obtained in the CDA with the canonical correlation $\left(\mathrm{r}_{\mathrm{c}}\right.$ ) of 0.95 (function 1) and 0.56 (function 2). Thus, White Fulani and Pasundan cows have closely of canonical plots (Figure 2). 
Table 1. Descriptive statistic of morphometrical measurements in White Fulani, Muturu and Pasundan cows

\begin{tabular}{lccc}
\hline \multirow{2}{*}{ Measurements $(\mathrm{cm})$} & \multicolumn{3}{c}{ Breed } \\
\cline { 2 - 4 } & White Fulani & Muturu & Pasundan \\
\hline Body length & $113.38 \pm 11.53^{\mathrm{a}}$ & $91.74 \pm 8.52^{\mathrm{b}}$ & $101.76 \pm 8.55^{\mathrm{c}}$ \\
Chest girth & $153.43 \pm 12.96^{\mathrm{a}}$ & $110.61 \pm 13.47^{\mathrm{b}}$ & $140.42 \pm 10.51^{\mathrm{c}}$ \\
Withers height & $120.06 \pm 14.85^{\mathrm{a}}$ & $73.81 \pm 7.52^{\mathrm{b}}$ & $114.07 \pm 7.40^{\mathrm{c}}$ \\
Rump length & $39.62 \pm 8.05^{\mathrm{a}}$ & $29.94 \pm 5.55^{\mathrm{b}}$ & $38.18 \pm 3.94^{\mathrm{a}}$ \\
Chest depth & $60.93 \pm 8.69^{\mathrm{a}}$ & $48.00 \pm 5.92^{\mathrm{b}}$ & $55.86 \pm 4.11^{\mathrm{c}}$ \\
\hline
\end{tabular}

Superscript in the different column differ significantly $(\mathrm{P}<0.05)$

Table 2. Factor selected by stepwise discriminant analysis to discriminate White Fulani, Muturu and Pasundan cows

\begin{tabular}{clcccc}
\hline Step & Variables entered & Tolerance & Fremove & $\mathrm{D}^{2}$ & Wilk's $\lambda$ \\
\hline 1 & Withers height & 0.17 & 117.13 & 2.44 & 0.19 \\
2 & Body length & 0.20 & 39.43 & 2.03 & 0.11 \\
3 & Rump length & 0.29 & 29.14 & 2.37 & 0.09 \\
4 & Chest girth & 0.18 & 8.23 & 2.35 & 0.07 \\
\hline
\end{tabular}

$\mathrm{D}^{2}=$ Mahalanobis distance

Table 3. Percentage (\%) of individual classification per breed based on discriminant analysis

\begin{tabular}{lcccc}
\hline \multirow{2}{*}{ Breed } & \multicolumn{2}{c}{ Predicted group membership (N) } & \multirow{2}{*}{ Total (N) } \\
\cline { 2 - 4 } & White Fulani & Muturu & Pasundan & \\
\hline White Fulani & $85.0(34)$ & $0.0(0)$ & $15.0(5)$ & $100.0(40)$ \\
Muturu & $0.0(0)$ & $100.0(40)$ & $0.0(0)$ & $100.0(40)$ \\
Pasundan & $25.6(10)$ & $0.0(0)$ & $74.4(29)$ & $100.0(39)$ \\
\hline N: number of animal & & & &
\end{tabular}

Table 4. The squared Mahalonobis distance $\left(\mathrm{D}^{2}\right)$ among White Fulani, Muturu and Pasundan based on their morphometrical measurements

\begin{tabular}{lccc}
\multicolumn{1}{c}{ Breed } & White Fulani & Muturu & Pasundan \\
\hline White Fulani & 0.00 & 4.31 & 1.50 \\
Muturu & - & 0.00 & 3.03 \\
Pasundan & - & - & 0.00 \\
\hline
\end{tabular}

In addition, four (4) morphometrics of CG, RL, BL and WH were identified as the discriminant variables in animals study (Table 2). Thus, four (4) steps of stepwise discriminant variable able to reduce the $\mathrm{D}^{2}$ value from 2.44 to 2.35 and Wilk's $\lambda$ from 0.19 to 0.07 . Moreover, the CDA of morphometrics able to classify White Fulani (85\%), Muturu $(100 \%)$ and Pasundan $(74.4 \%)$ into their original breed group (Table 3). Moreover, the closest of Euclidean distance was showed in White Fulani and Pasundan cows (1.50). Meanwhile, Muturu showed more distance from Pasundan (3.03) and White Fulani (4.31) as presented in Table 4. In addition, according to the morphometrics $\mathrm{D}^{2}$ distance, White Fulani and Pasundan cattle were grouped into a similar cluster and Muturu was grouped into separated cluster (Figure 3).

\section{DISCUSSIONS}

Generally, the morphometrics in the animals study were different and can be caused by genetical factor. White Fulani and Pasundan cattle breeds have genetic introgression from Zebu cattle (Bos indicus). Hence, some physical characteristics and morphometrical measurements in both breeds were observed similarly. The differences of morphometrics between cattle breeds with the same age might be caused by genetic factors. Therefore, four (4) discriminant variables that were obtained in this study can 


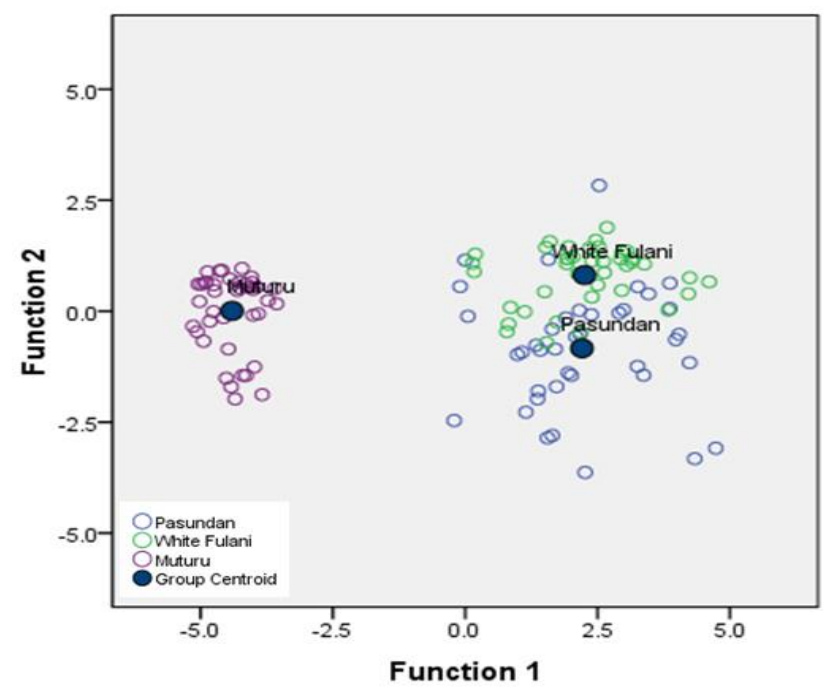

Figure 2. Canonical discriminant plot in the morphometrical measurements to characterize of White Fulani, Muturu and Pasundan cows

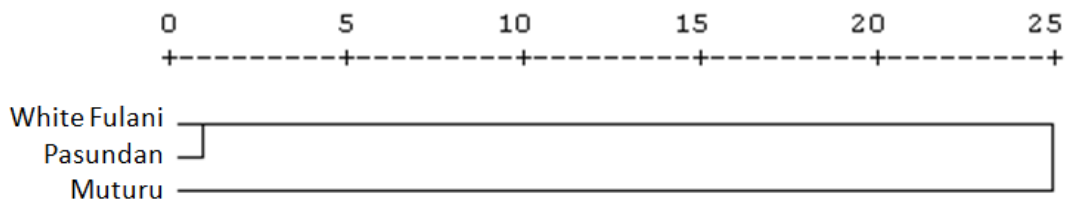

Figure 3. Dendogram distance among White Fulani, Muturu and Pasundan cows based on the morphometrical measurements

be used to discriminate breeds study without phenotypic observation. Pundir et al. [8] obtained six (6) discriminant variables of withers height, body length, ear length, tail length without switch, paunch girth and face length that able to discriminate three Indian indigeneous cows of Tripura, Manipur and Mizoram. Yakubu et al. [9] obtained three (3) discriminant variables of rump width, withers height and face length that able to discriminate Bunaji and Sokoto Gudali cattle. Merga et al. [10] obtained five (5) disciminant variables of heart girth, withers height, horn length, neck length and tail length that able to discriminate Arsi, Kereyu and their crossbred cattle. Putra et al. [11] obtained three (3) discriminant variables of chest girth, chest depth and body length that able to discriminate two Indonesian indigenous cattle of Ongole and Pasundan bulls. Edouard et al. [14] obtained nine (9) discriminant variables of head length, head width, skull length, chest length, heart girth, chest depth, body length and muzzle length that able to discriminate N'Dama cattle from two different populations. Anya et al. [15] obtained the $r_{c}$ value of 0.85 (function 1) and 0.75 (function 2) with four (4) discriminate variables of horn circumference, cannon length, udder circumference and head width to discriminate Nigerian cattle from different coat colour groups. Goitom et al. [16] obtained four (4) discriminate variables of body length, chest girth, withers height and dewlap width that able to discriminate Eritrean cattle from two (2) different populations. Congo et al. [17] has been worked with CDA of morphometrics in Ecuadorian Creole cattle and obtains the $r_{c}$ value of 0.94 (function 1), 0.85 (function 2) and 0.41 (function 3). Thus, Shaibu et al. [18] obtained the $r_{c}$ value of 0.62 (function 1), 0.45 (function 2), 0.36 (function 3) and 0.34 (function 4) with five (5) discriminant variables (horn length, muzzle circumference, body length, chest girth and ear length) for discriminating Muturu cows at different locations. Lombebo et al. [19] obtained seven (7) discriminant variables of withers height, ear length, pelvic width, tail length, rump height, body length and rump height that able to discriminate Ethiopian indigenous cows. Hence, previous studies reported that the CDA of morphometrics able to classify many cattle breeds of Tripura $(84.13 \%)$, 
Mizoram (82.09\%), Manipur (79.87\%), Bunaji (85.48\%), Sokoto Gudali (96.55\%), Pasundan $(100 \%)$ and Ongole $(100 \%)$ cattle into their original breed group $[8,9,11]$. Despite, the CDA of morphometrics able to classify the Eritrean cattle at highland $(77.0 \%)$, lowland (100\%) and coastland (78\%) into their original population [16]. Therefore, Merga et al. [10] reported that the $\mathrm{D}^{2}$ distance of cattle from Fentale and Boset districts was 1.53 and close to the $\mathrm{D}^{2}$ value between White Fulani and Pasundan cows. The number of discriminant variable can be affected by type of observed breeds, type of measurements and management system. In this study, the management system of animal study was showed different. Nevertheless, the effect of management system can be reduced with selecting non-inbred animals, similar sex and similar age of animal for the analysis. Furthermore, the skull measurements (craniometrics) were more accurate for discriminating some breeds than using some morphometrical measurements [20]. Unfortunately, study to observe the kinship among Pasundan, White Fulani and Muturu cattle based on mtDNA information was not reported before. However, the presence of Bos indicus introgression may be contributed to the close relationship between White Fulani and Pasundan cattle.

\section{CONCLUSIONS}

To conclude, an overlapping CDA was observed between White Fulani and Pasundan cattle breeds while the muturu cattle greatly differ from both breeds. This relationship is a signal to possible genetic relationship between White Fulani and Pasundan cattle. Thus, we utilized CDA to differentiate morphological measurements of the three cattle breeds with four morphometric measurements (CG, RL, BL, $\mathrm{WH}$ ) as discriminant variables.

\section{CONFLICT OF INTEREST}

The authors declare no conflict of interest with any financial organization regarding the material discussed in the manuscript.

\section{REFERENCES}

1. Pitt, D., N. Sevane, E. L. Nicolazzi, D. E. MacHugh, S. D. E. Park, L. Coll, R. Martinez, M. W. Bruford, and O. W. Pablo. 2017. Domestication of cattle: Two or three events? Evol. Appl. 12:123-136. Doi: 10.1111/eva.12674

2. Utsunomiya, Y. T., M. Milanesi, M. R. S. Fortes, L. R. Porto-Neto, A. T. H. Utsunomiya, M. V. G. B. Silva, J. F. Garcia, and P Ajmone-Arsan. 2019. Genomic clues of the evolutionary history of Bos indicus cattle. Anim. Genet. 50:557-568. Doi: 10.1111/age.12836

3. Hartatik T, D. N. H. Hariyono, and Y. Adinata. 2019. Genetic diversity and phylogenetic analysis of two Indonesian local cattle breeds based on cytochrome-b gene sequences. Biodiversitas. 20:17-22. Doi: 10.13057/biodiv/d200103

4. Wulandari, A., V. M. A. Nurgiartiningsih, Kuswati, T. E. Susilorini, and P. P. Agung. 2019. Kinship of several Indonesian local cattle by using DNA mitochondrial COI (Cytochrome Oxidase Sub-unit I). Int. Res. J. Adv. Eng. Sci. 4:165-167.

5. Laosutthipong, C. and P. Chuawongboon. 2018. Genetic relationship of maternal lineages in Phetchaburi native cattle. Int. J. Agric. Tech. 14:1379-1390.

6. Abdulfatai, T., Y. T. Utsonomiya, A. G. Ezekwe, O. Nashiru, and O. Hanotte. 2019. Genome sequence analysis reveals selection signatures in endangered Trypanotolerant West African Muturu cattle. Front. Genet. 10. Doi: org/10.3389/ fgene.2019.00442

7. Boujenane I, L. Derqaoui, and G. Nouamane. 2016. Morphological differentiation between two Marocco goat breeds. J. Livest. Sci. Tech. 4:31-38.

8. Pundir, R. K., P. K. Singh, and D. K. Sadana. 2015. Multivariate analysis of morphometric traits of three different indigenous cattle populations from North East States of India. JITV. 20:79-86. Doi: 10.14334/jitv.v20i2.1162

9. Yakubu, A., K. O. Idahor, H. S. Haruna, M. Wheto, and S. Amusan. 2010. Multivariate analysis of phenotypic differentiation in Bunaji and Sokoto Gudali cattle. Acta 
Agric. Slov. 96:75-80. Doi: 10.2478/v10014010-0018-9

10. Merga, Y. N. and Y. Tadesse. 2020. Morphological variations of Arsi, Kereyu and their crossbred cattle under current climate change in Mid Rift Valley of Oromia, Ethiopia. Res. J. Agric. Sci.Res. 8:630-648. Doi: 10.14662/ARJASR2020.440

11. Putra, W. P. B., F. Hilmawan, and J. Arifin. 2020. Characterization in two Indonesian Bos indicus cattle breeds based on morphometrical measurements. Turk. J. Vet. Res. 4:29-32.

12. Ozkaya S. and Y. Bozkurt. 2008. The relationship of parameters of body measures and body weight by using digital image analysisin pre-slaughter cattle. Arch. Tierz. 51:120-128. Doi: 10.5194/aab51-120-2008

13. Alderson, G. L. H. 1999. The development of a system of linear measurements toprovide an assessment of type and function of beef cattle. AGRI. 25:45-55.

14. Edouard, N. K., B. K. Lacine, K. N. Cyrille, L. K. Etienne, G. K. Dayo, S. Mamadou, and Y. G. C. Valentine. 2018. Multivariate analysis for morphological characteristics of N'Dama cattle breed in two agroecological zones of Cote de Ivoire. Europ. Sci. J. 14:603-621. Doi: 10.19044/esj.2018. v14n3p602

15. Anya, M. I., O. B. Dauda, A. Ayuk, and M. G. Chukwumati. 2018. Phenotypic characterization of cattle based on coat colour in Obudu grass plateau, Southsouth Nigeria: A discriminant approach. Nigerian J. Anim. Sci. 20:1-9.

16. Goitom, S., M. G. Gicheha, K. Ngeno, and F. K. Njonge. 2019. Morphological characterisation of indigenous cattle breeds in Eritrea. Adv. Anim. Vet. Sci. 7:848-857.

17. Congo, R. C., C. B. Capote, A. G. Martinez, O.C. Falquez, J. M. L. Jurado, J. M. A. Reyes, and A. G. Martinez. 2019. Biometric study of Criollo Santa Elena Peninsula cattle (Ecuador). Rev. Mex. Cienc. Pecu. 10:819-836. Doi: 10.22319/rmcp.v10i4.4850

18. Shaibu, S. S., D. S. Gwasa, J. O. Egahi, and H. Elkana. 2021. Application of the discriminant analysis on the forest Muturu cattle in different locations in Southern Zone of Nigeria. AJB2T. 7:12-19. Doi: 10.7934/AJB2T/2021/v7i230096

19. Lombebo W. A. and N. A. Zeleke. 2018. On farm phenotypic characterization of local cattle populations in Hadiya Zone, Southern Region, Ethiopia. Adv. Dairy. Res. 6. Doi: 10.4172/2329-888x.1000218

20. Popoola, M. A., and S. O. Oseni. 2018. Multifactorial discriminant analysis of cephalic morphology of indigenous breeds of sheep in Nigeria. Slovak. J. Anim. Sci. 51:45-51. 